\title{
PENGEMBANGAN PERANGKAT PRAKTIKUM ILMU PENGETAHUAN BUMI DAN ANTARIKSA BERBASIS KEMAMPUAN GENERIK SAINS UNTUK MENINGKATKAN KETERAMPILAN LABORATORIUM CALON GURU FISIKA
}

\author{
Ni Made Pujani \\ Jurusan Pendidikan Fisika, Fakultas Matematika dan Ilmu Pengetahuan Alam \\ Universitas Pendidikan Ganesha, \\ Singaraja Indonesia \\ e-mail: pujanim@yahoo.co.id
}

\begin{abstract}
Abstrak
Studi menggunakan Research and Development ( $R$ \& $D$ ) tahun pertama ini dilakukan untuk menghasilkan Perangkat Pembelajaran Praktikum Berbasis Kemampuan Generik Sains (P3BKGS) bagi calon guru fisika. Penyusunan perangkat pembelajaran diawali dengan analisis kebutuhan melalui studi literatur dan lapangan. Draft P3BKGS untuk IImu Pengetahuan Bumi dan Antariksa (IPBA) ini terdiri dari 10 topik praktikum, masing-masing lima topik praktikum kebumian dan astronomi. Karakteristik pembelajaran P3BKGS diawali dengan melakukan eksplorasi terhadap program simulasi, menyusun rancangan praktikum IPBA berbasis kemampuan generik sains secara kelompok, membuat alat peraga, berkolaborasi dalam menyempurnakan dan melaksanakan rancangan kelompok, melakukan presentasi dan diskusi, serta melaporkan hasil kegiatan secara mandiri. Instrumen yang disusun adalah tes paktikum, tes kemampuan generik sains, lembar observasi, dan angket respon. P3BKGS diharapkan dapat mengembangkan keterampilan laboratorium, kemampuan generik sains, meningkatkan keterlibatan mahasiswa secara aktif selama proses pembelajaran dan memungkinkan mahasiswa belajar lebih mandiri. Selanjutnya draft P3BKGS ini akan divalidasi melalui uji coba terbatas dan uji coba luas untuk penyempurnaan.
\end{abstract}

Kata-kata Kunci: calon guru fisika, kemampuan generik sains, keterampilan laboratorium, pengembangan, perangkat praktikum

\begin{abstract}
A study using the first year $R$ \& $D$ is conducted to produce a Generic Science Ability Based Practical Learning Tool (GSABPLT) for physics teacher prospective. Setting the learning tool was begun with a need analysis through the literature studies and field studies. Draft of earth and space science GSABPLT consists of 10 lab topics, where the five topics are earth practicum and five other are astronomical topics. The characteristics of GSABPLT learning is begun with the exploration towards the simulation program, setting grouply the draft of Generic
\end{abstract}


Science Ability based earth and space science Lab, making visual aid tool, collaborating in improving and implementing the design of group, conducting the presentations and discussions, and reporting the results of activities independently as well. The instruments composed are practical test, generic science ability test, observation sheets, and student questionnaire responses. The GSABPLT is expected to develop laboratory skills, generic science ability, to increase the students' engagement actively during the learning process and allow the students to learn more independently. Furthermore, the GSABPLT draft will be validated through the limited test and extensive test for the improvement.

Keywords: physics teacher prospective, generic science ability, laboratory skills, development, lab devices.

\section{PENDAHULUAN}

Salah satu permasalahan penting dalam pembelajaran IImu Pengetahuan Bumi dan Antariksa (IPBA) di Jurusan Fisika, baik bidang Kebumian maupun Astronomi adalah rendahnya kualitas pembelajaran pada berbagai jenjang pendidikan. Rendahnya kualitas proses dan hasil belajar IPBA dipengaruhi banyak faktor, salah satunya adalah guru. McDermot (1990) menyatakan bahwa salah satu faktor penting yang mempengaruhi rendahnya kinerja pendidikan sains adalah kurangnya guru-guru yang dipersiapkan dengan baik. Sementara menurut NRC (1996), dalam pengembangan profesional guru, harus diberikan keterampilan praktikum, sehingga calon guru dapat mengembangkan pengetahuan, pengertian dan kecakapannya.

Fakta di lapangan menemukan bahwa pembelajaran IPBA di sekolahsekolah dan di perguruan tinggi belum didukung dengan kegiatan praktikum (Pujani dan Liliasari, 2011). Pembelajaran IPBA didominasi oleh ceramah, tanya jawab dan penugasan. Dosen dan guru tidak pernah mengajarkan IPBA melalui kegiatan laboratorium. Hal ini sejalan dengan temuan Depdiknas (2002), bahwa pembelajaran sains di sekolah umumnya bersifat teoritis, melalui ceramah, diskusi, dan penyelesaian soal, tanpa eksperimen ataupun demonstrasi. Terhadap hal ini banyak alasan umum yang dikemukakan, antara lain karena guru tidak pernah dilatih melaksanakan praktikum IPBA, tidak adanya ruang laboratorium, dan tidak ada alat-alat praktikum IPBA.

IPBA sebagai bagian dari sains seharusnya dibelajarkan melalui kegiatan praktikum, karena praktikum merupakan bagian integral dari kegiatan belajar mengajar (Rustaman et al., 2005), dan salah satu faktor penentu keberhasilan pembelajaran praktikum adalah guru (Lazzarowitz and Tamir, 1994). Selain itu, hasil penelitian menunjukkan bahwa kemampuan guru dalam mengelola laboratorium berpengaruh positif terhadap frekwensi penggunaan laboratorium (Rustad et al., 2004). Melalui pembelajaran IPBA dengan kegiatan praktikum, mahasiswa akan memperoleh pengalaman secara langsung, sehingga dapat meningkatkan penguasaan konsep, kemampuan memecahkan masalah dan keterampilan-keterampilan ilmiah, memahami bagaimana sains dan 
ilmuwan bekerja, menumbuhkan minat dan motivasi, serta melatih keterampilan berpikir (Hofstein and Mamlok-Naaman, 2007). Keterampilan berpikir yang dapat dikembangkan antara lain kemampuan generik sains (Brotosiswoyo, 2000).

Kemampuan generik sains adalah keterampilan berpikir dan bertindak berdasarkan pengetahuan sains yang dimilikinya yang diperoleh setelah mahasiswa belajar sains (Liliasari, 2005). Kemampuan generik sains merupakan kemampuan yang dapat digunakan untuk mempelajari berbagai konsep dan menyelesaikan masalah dalam sains (Brotosiswoyo, 2000). Oleh karena itu, kemampuan generik sains merupakan kemampuan yang digunakan secara umum dalam berbagai kerja ilmiah, dan dapat digunakan sebagai landasan dalam melakukan kegiatan laboratorium. Banyak kemampuan generik yang dapat dikembangkan melalui praktikum, misalnya mengambil keputusan, pemecahan masalah, komunikasi, kerja kelompok, dan penalaran tingkat tinggi (Gibb, 2002).

Indikator-indikator kemampuan generik sains ini beririsan dengan indikator keterampilan proses di mana aspek keterampilan proses meliputi: (1) mengamati, (2) merumuskan hipotesis, (3) meramalkan, (5) menyelidiki/meneliti, (5) menginterpretasikan penemuan dan menarik kesimpulan, serta mengkomunikasikan (Herlen.W, 1992; Iskandar, 1997). Ada kesamaan ini memungkinkan dilaksanakannya pembelajaran kegiatan praktikum dengan berbasis kemampuan generik sains untuk meningkatkan hasil belajar, keterampilan laboratorium, dan kemampuan generik sains mahasiswa.
Manfaat yang dapat diperoleh dengan menggunakan kemampuan generik sains sebagai landasan dalam pembelajaran praktikum IPBA antara lain: (1) Kemampuan generik sains membantu guru meningkatkan cara belajar siswa; (2) Pembelajaran yang memperhatikan kemampuan generik sains dapat mempercepat pembelajaran; dan (3) Siswa yang berlatih kemampuan generik sains dapat mengatur kecepatan belajarnya sendiri dan yang diatur oleh guru sesuai dengan kecepatan pembelajaran.

Beberapa penelitian tentang model pembelajaran fisika dengan kegiatan laboratorium telah berhasil mengembangkan kemampuan generik sains. Pada pembelajaran fisika modern (Hartono, 2006) dapat mengembangkan kemampuan generik sains kesadaran akan skala besaran, bahasa simbolik, inferensi logika, hubungan sebab akibat dan pemodelan. Penelitian yang dilakukan oleh Pujani (2010) terhadap pembelajaran praktikum Kebumian dapat mengembangkan tujuh dari sembilan kemampuan generik sains, yaitu pengamatan langsung, pengamatan tak langsung, kesadaran akan skala besaran, bahasa simbolik, inferensi logika, hubungan sebab akibat, dan pemodelan.

Mengingat belum semua kemampuan generik sains dapat berkembang dengan baik, dan perlunya seorang guru memiliki kemampuan generik sains, serta begitu pentingnya penguasaan keterampilan laboratorium dalam merancang dan melaksanakan kegiatan praktikum oleh calon guru, maka perlu dilakukan penelitian untuk dapat mengembangkan semua kemampuan generik sains dan 
keterampilan laboratorium IPBA, dengan judul "Pengembangan Perangkat Praktikum IPBA Berbasis Kemampuan Generik Sains Bagi Calon Guru Fisika".

Berdasarkan latar belakang masalah di atas dapat dirumuskan masalah penelitian, sebagai berikut.

1) Perlu dikembangkan suatu perangkat pembelajaran praktikum IPBA berbasis kemampuan generik sains bagi mahasiswa calon guru fisika agar dapat merencanakan, melaksanakan, dan melaporkan kegiatan laboratorium IPBA.

2) Perlu dikembangkan model pembelajaran praktikum agar dapat mengembangkan keterampilan praktikum dan kemampuan generik sains mahasiswa calon guru fisika.

3) Perlu dikembangkan suatu model asesmen dalam pembelajaran praktikum IPBA agar dapat mengukur keterampilan praktikum dan kemampuan generik sains mahasiswa calon guru fisika.

Penelitian ini merupakan penelitian pendidikan dan pengembangan multiyears. Pada tahun pertama ini bertujuan untuk mengumpulkan berbagai informasi dalam rangka menetapkan kondisikondisi dan persyaratan-persyaratan empiris dan teoritis yang diperlukan (analisis kebutuhan) untuk merancang draft perangkat praktikum IPBA berbasis kemampuan generik sains. Draft yang akan disusun meliputi: Modul praktikum IPBA berbasis kemampuan generik sains, panduan pembelajaran praktikum IPBA untuk dosen, tes keterampilan praktikum, tes kemampuan generik sains berbasis konten, rubrik penilaian, dan pedoman observasi. Dengan demikian, produk penelitian pada tahun pertama adalah draft perangkat praktikum IPBA berbasis kemampuan generik sains lengkap dengan asesmennya. Adapun manfaat Penelitian adalah menemukan prinsipprinsip, dalil-dalil atau kaidah-kaidah yang dapat dijadikan acuan bagi pihak LPTK dan dosen dalam menerapkan model praktikum bagi peningkatan keterampilan laboratorium mahasiswa calon guru di Jurusan Pendidikan Fisika.

Keterampilan laboratorium atau keterampilan praktikum merupakan suatu unsur yang penting dalam kegiatan belajar mengajar sains (Millar, 2004; Hofstein and Lunetta, 2004). Kegiatan praktikum yang dilakukan di laboratorium maupun di luar laboratorium seperti di kelas atau di alam terbuka, berkaitan dengan suatu bidang ilmu tertentu yang antara lain ditujukan untuk menunjang pembelajaran teori, (Hofstein and Mamlok-Naaman, 2007; Rustaman et al., 2005; dan Margono, 2000).

Dalam Laboratory Report America (Tn, 2005) dinyatakan bahwa keterampilan praktikum yang dikembangkan dalam laboratorium sains di sekolah hendaknya dapat membantu memperbaiki pemahaman dan pengertian tentang sains, serta mempersiapkan ilmuwan melalui kegiatan laboratorium. Secara lebih spesifik Brotosiswoyo (2000) menyatakan bahwa kemampuan yang perlu dikembangkan dalam kegiatan laboratorium adalah: keterampilan dalam menyiapkan rancangan kegiatan praktikum, melaksanakan dan melaporkan hasil kegiatan praktikum.

Jurnal Pendidikan Indonesia |474 


\section{METODE PENELITIAN}

Metode penelitian yang digunakan adalah metode Penelitian dan Pengembangan dengan model 3D, yaitu Define, Design, dan Develop (modifikasi model 4D dari Thiagarajan et al., 1974). Define adalah kegiatan mengumpulkan berbagai informasi yang diperlukan (needs assessment). Design adalah kegiatan merancang produk awal atau draft perangkat pembelajaran. Develop adalah kegiatan mengembangkan produk.

Kegiatan penelitian yang dilakukan pada tahun pertama ini adalah mengumpulkan informasi (define atau needs assessment) melalui studi literatur dan studi lapangan, yang dilanjutkan dengan pembuatan draft perangkat pembelajaran praktikum berbasis kemampuan generik sains (design). Studi lapangan dilakukan pada 20 sampel SMP/SMA di Kota Singaraja dan satu sampel LPTK Negeri di Bali. Selanjutnya, hasil-hasil studi literatur dan studi lapangan digunakan sebagai bahan untuk merancang draft perangkat pembelajaran praktikum berbasis kemampuan generik sains yang siap divalidasi oleh pakar dan diuji coba terbatas pada tahun kedua.

Data dikumpulkan dengan metode observasi, wawancara dan pencatatan dokumen. Semua data yang diperoleh pada analisis kebutuhan merupakan data kualitatif. Data kualitatif dianalisis secara deskriptif interpretatif melalui sintesis hasil-hasil yang diperoleh.

\section{HASIL DAN PEMBAHASAN}

\section{Hasil Studi Literatur}

Hasil studi literatur/pustaka terhadap kurikulum IPBA di SMP, SMA dan LPTK memberikan informasi tentang ruang lingkup dan kedalaman materi IPBA yang diberikan di sekolah dan LPTK. Pada prinsipnya, materi IPBA yang diberikan di LPTK dimaksudkan untuk membekali calon guru fisika agar nantinya mampu mengajar IPBA di SMP dan SMA. Kurikulum yang digunakan di Jurusan Pendidikan Fisika pada suatu LPTK adalah kurikulum yang berdasarkan pada kompetensi. Pada kurikulum Fisika, materi IPBA muncul di semester III. Cakupan materi yang diajarkan adalah Struktur bumi, Litosfer, Hidrosfer, Atmosfer, Bola langit, Tata surya, Sistem bumi-bulan, Pengenalan jagat raya

Berdasarkan hasil analisis KTSP, materi IPBA yang ditawarkan di SMP maupun SMA tidak lagi sepenuhnya terintegrasi pada mata pelajaran IPA atau fisika sebagai mana dalam kurikulum sebelumnya. Ruang lingkup pemberian materi IPBA di SMP adalah Tata surya, Matahari sebagai bintang dan bumi sebagai salah satu planet, Gerak edar bumi, bulan dan satelit buatan, Litosfer dan atmosfer berhubungan dengan zat dan kalor, Atmosfer dan hidrosfer, bentuk bumi. Ruang lingkup materi IPBA di SMA: Keteraturan Gerak Planet dalam tata surya berdasarkan hukum-hukum Newton, Sejarah pembentukan bumi, Tata surya dan jagat raya, Litosfer, Atmosfer, Hidrosfer

Dalam KTSP, materi IPBA tidak terintegrasi sepenuhnya di IPA atau 
fisika, di mana topik yang dikaji dalam IPA atau fisika berkurang dari kurikulum sebelumnya. Topik IPBA di SMP, selain diintegrasikan pada mata pelajaran IPA juga ada di IPS. Demikian pula topik IPBA di SMA, selain diintegrasikan pada mata pelajaran fisika sebagian besar diintegrasikan pada pelajaran geografi. Kondisi ini tentu berdampak pada kurangnya pengetahuan dan pemahaman siswa terhadap materi IPBA. Sebagaimana diketahui landasan keilmuan untuk belajar IPBA adalah fisika dan matematika. Bila dimasukkan dalam mata pelajaran geografi akan ada banyak keterbatasan kemampuan guru dalam mengajarkan IPBA dengan benar. Minimnya wawasan guru terhadap IPBA tentu berpengaruh pada kurangnya penguasaan siswa terhadap
IPBA. Selain itu, konten materi IPBA yang diberikan di Sekolah kurang mencukupi dalam mempersiapkan siswa menghadapi Olimpiade Sains Nasional bidang Astronomi dan Kebumian.

Selain mempertimbangkan kesesuaian materi kurikulum, pemilihan topik kegiatan laboratorium juga didasarkan pada rekomendasi dari Lippmann (2003), yaitu materi tersebut digunakan oleh ilmuwan, berguna di masa datang bagi siswa, dan dapat diajarkan di laboratorium. Berdasarkan pertimbangan tersebut, sebagai program rintisan pelaksanaan kegiatan laboratorium IPBA ditetapkan 10 topik praktikum, meliputi lima topik Kebumian dan lima topik Astronomi. Topik praktikum dan peralatan pendukung yang diperlukan disajikan pada Tabel 1 .

Tabel 1 Topik Kegiatan Laboratorium IPBA yang Dikembangkan

\begin{tabular}{|c|c|c|c|}
\hline $\begin{array}{l}\text { No } \\
\text { LKM }\end{array}$ & $\begin{array}{l}\text { Materi } \\
\text { IPBA }\end{array}$ & $\begin{array}{c}\text { Topik yang } \\
\text { dikembangkan }\end{array}$ & Peralatan yang dibutuhkan \\
\hline \multicolumn{4}{|c|}{ KEBUMIAN } \\
\hline 1 & Litosfer & Identifikasi Batuan & $\begin{array}{l}\text { Sampel batuan, lup, komparator dan } \\
\text { software siklus batuan }\end{array}$ \\
\hline 2 & $\begin{array}{l}\text { Tektonik } \\
\text { Lempeng }\end{array}$ & $\begin{array}{l}\text { Pemekaran Dasar } \\
\text { Samudra }\end{array}$ & $\begin{array}{l}\text { Alat percobaan sederhana dan software } \\
\text { tektonik lempeng }\end{array}$ \\
\hline 3 & $\begin{array}{l}\text { Tenaga } \\
\text { Eksogen }\end{array}$ & Erosi dan Pelapukan & $\begin{array}{l}\text { Alat percobaan sederhana dan video } \\
\text { tentang perbedaan erosi dan pelapukan }\end{array}$ \\
\hline 4 & Hidrosfer & Siklus Air & $\begin{array}{l}\text { Alat percobaan sederhana dan software } \\
\text { tentang siklus air }\end{array}$ \\
\hline 5 & Atmosfer & Efek Rumah Kaca & $\begin{array}{l}\text { Alat percobaan sederhana dan software } \\
\text { tentang efek rumah kaca }\end{array}$ \\
\hline \multicolumn{4}{|c|}{ ASTRONOMI } \\
\hline 6 & Matahari & Jam Matahari & $\begin{array}{l}\text { Alat percobaan sederhana dan software } \\
\text { gerak semu harian matahari }\end{array}$ \\
\hline 7 & Bumi & $\begin{array}{l}\text { Rotasi dan Revolusi } \\
\text { Bumi }\end{array}$ & $\begin{array}{l}\text { Bola bumi, senter, dan software pergantian } \\
\text { musim }\end{array}$ \\
\hline 8 & Bulan & $\begin{array}{l}\text { Rotasi dan Revolusi } \\
\text { Bulan }\end{array}$ & $\begin{array}{l}\text { Model Matahari-Bumi-Bulan dan software } \\
\text { fasa bulan }\end{array}$ \\
\hline
\end{tabular}




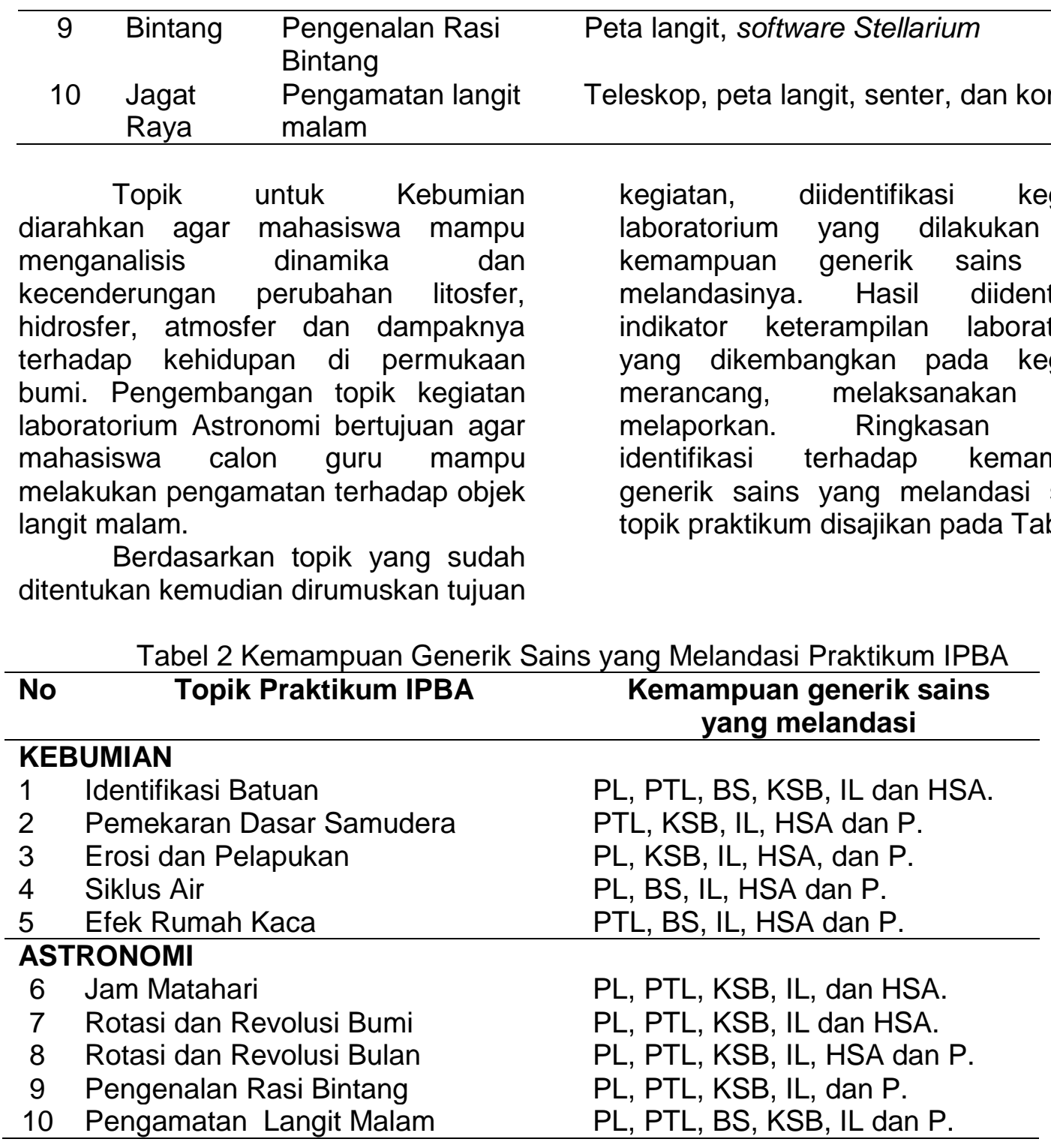

Keterangan: $\mathrm{PL}=$ pengamatan langsung, $\mathrm{PTL}=$ pengamatan tak langsung, $\mathrm{KSB}=$ kesadaran akan skala besaran, BS bahasa simbolik, IL = inferensi logika, $\mathrm{HSA}=$ hubungan sebab akibat, dan $\mathrm{P}=$ pemodelan .

Berdasarkan Tabel 2, teridentifikasi ada tujuh kemampuan generik sains yang melandasi kegiatan laboratorium IPBA, yaitu pengamatan langsung $(\mathrm{PL})$, pengamatan tak langsung ( $\mathrm{PTL})$, kesadaran akan skala besaran (KSB), bahasa simbolik (BS), inferensi logika (IL), hubungan sebab 
akibat (HSA) dan pemodelan (P). Banyaknya kemampuan generik sains yang dapat dikembangkan tergantung pada karakteristik materi dan kegiatan praktikum yang dilakukan.

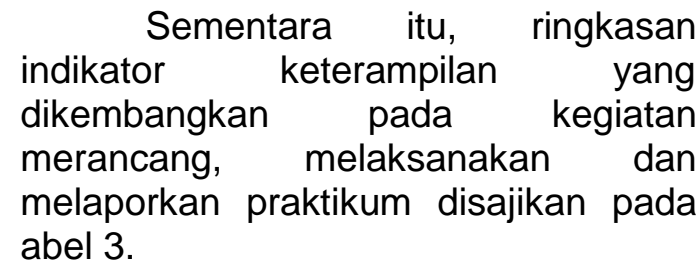

Tabel 3 Keterampilan yang Dikembangkan pada Kegiatan Praktikum IPBA

\begin{tabular}{lll}
\hline No & $\begin{array}{c}\text { Keterampilan } \\
\text { Praktikum }\end{array}$ & \multicolumn{1}{c}{ Indikator } \\
\hline 1 & Merancang & 1. Merumuskan judul \\
& Kegiatan & 2. Mengidentifikasi masalah \\
& Praktikum & 3. Merumuskan tujuan \\
& 4. Mengidentifikasi kemampuan generik sains yang \\
& 5. Menentukan konsep dan prinsip \\
& 6. Merumuskan hipotesis \\
& 7. Mengidentifikasi variabel \\
& 8. Menentukan cara mengukur variabel terikat \\
& 9. Mengenali alat dan bahan \\
& 10. Menyusun langkah kerja \\
& 11. Merancang alat evaluasi \\
& Melaksanakan & 1. Mengaplikasikan rancangan \\
& 2. Menggunakan alat dan bahan \\
& 3. Melakukan pengamatan \\
& 4. Mencatat hasil \\
& 5. Mempresentasikan hasil \\
& 6. Diskusi \\
\hline Praktikum & 1. Membuat analisis data \\
& 2. Membuat interpretasi hasil \\
& 3. Membuat pembahasan \\
& 4. Menarik kesimpulan
\end{tabular}

Berdasar Tabel 3 diketahui, ada 11 indikator pada keterampilan merancang, enam keterampilan pada keterampilan melaksanakan praktikum dan enam keterampilan pada kegiatan melaporkan praktikum. Indikator keterampilan membuat laporan pada Tabel 3 merupakan indikator utama.
Dalam penskoran kinerja produk (laporan) juga disertakan penskoran terhadap sebagian dari indikator keterampilan merancang, seperti merumuskan judul, tujuan, kemampuan generik sains, dasar teori, alat dan bahan, langkah kerja dan keterkaitan 
antar indikator laporan, sesuai dengan format penyusunan laporan.

\section{Hasil Studi Lapangan}

Studi lapangan dimaksudkan untuk mengumpulkan berbagai informasi yang ada di lapangan agar dapat merancang program.

\section{1) Pelaksanaan Pembelajaran IPBA}

Perkuliahan IPBA di jurusan fisika pada suatu LPTK di Singaraja Bali berlangsung di ruang kelas. Dosen yang mengampu mata kuliah ini kiranya perlu meninjau kembali agar materi yang disajikan lebih relevan dengan sifat mata kuliah IPBA sebagai kelompok mata kuliah sains khususnya physical science yang dekat dengan kehidupan sehari-hari. Selama perkuliahan digunakan metode presentasi dan diskusi. Pembelajaran dengan kegiatan laboratorium belum terlaksana, walaupun telah tersedia peralatan lab dan manualnya. Demikian pula upaya untuk meningkatkan aktivitas perkuliahan dengan menggunakan asesmen yang bervariasi belum pernah dilakukan. Dosen lebih sering memberikan penugasan dalam bentuk pembuatan makalah. Quis atau tes kecil tidak diberikan, sehingga nilai akhir cenderung hanya bersumber dari penilaian UTS, UAS, tugas presentasi.

Selama kuliah berlangsung, respon mahasiswa terhadap perkuliahan cenderung agak pasif. Dosen dapat meningkatkan aktivitas perkuliahan ini dengan memvariasi metode perkuliahan sehingga tidak monoton dan mampu meningkatkan motivasi perkuliahan. Mayoritas mahasiswa mengatakan, pada awalnya mereka tertarik dengan perkuliahan ini karena membayangkan akan mempelajari hal-hal yang dapat menyingkap keajaiban alam semesta. Namun setelah kuliah berjalan relatif monoton ada terkesan kebosanan, hal ini cenderung menurunkan motivasi dan aktivitas belajar mahasiswa, akhirnya akan bermuara pada capaian hasil belajar yang rendah pula.

Pelaksanaan pembelajaran IPBA di sekolah-sekolah memberi gambaran yang hampir sama dengan di LPTK. Hasil observasi di beberapa SMP/SMA Negeri dan Swasta di Singaraja menemukan bahwa metode pembelajaran yang digunakan didominasi metode ceramah dan tugas. Bahkan materi IPBA ini cenderung diberikan sepintas saja karena standar kompetensinya hanya 1-2 dari keseluruhan standar kompetensi IPA atau fisika. Porsi yang kecil ini menyebabkan pelaksanaan pembelajaran IPBA tidak menjadi prioritas bahkan cenderung dikesampingkan. Karena kendala waktu, seorang guru menyatakan pernah hanya menugaskan ke siswa saja untuk membaca sendiri materi tersebut.

Pelaksanaan pembelajaran sama sekali tidak pernah memberikan praktikum. Untuk beberapa sekolah yang gurunya pernah mendapat pelatihan, mengaku pernah mengajar IPBA dengan menggunakan media gambar seperti gambar galaksi, selebihnya pembelajaran dilakukan secara klasikal.

\section{2) Petunjuk Praktikum dan Fasilitas Lab IPBA}

Hampir semua responden menyatakan bahwa selama 
pembelajaran IPBA di sekolah menengah maupun LPTK, dosen dan guru tidak pernah melakukan pembelajaran dengan melakukan kegiatan laboratorium. Untuk di LPTK, karena dalam kurikulum bobot perkuliahan ini 3 sks yang mengindikasikan perkuliahan di ruang kelas saja tanpa praktikum. Di sekolahsekolah, praktek tidak diberikan selain karena tidak tersedianya peralatan praktek juga disebabkan karena guru belum memiliki kemampuan dalam merancang maupun melaksanakan praktikum IPBA.

Di LPTK ditemukan sudah ada petunjuk praktikum, walaupun masih berupa petunjuk singkat seperti manual alat dan jumlahnya terbatas. Komponen yang tertuang dalam petunjuk pun masih terbatas, yaitu tujuan, teori yang melandasi dan prosedur singkat. Petunjuk ini masih perlu disempurnakan lagi dan perlu dipikirkan untuk membuat petunjuk praktikum yang tidak hanya melatihkan hand on tetapi juga mind on siswa. Praktikum yang melatih siswa untuk berpikir dan bertindak berdasarkan sains antara lain yang berbasis kemampuan generik sains.

Fasilitias pendukung kegiatan laboratorium IPBA pada suatu LPTK di Singaraja masih sangat kurang. Peralatan yang ada untuk praktikum astronomi adalah model tata surya (1 buah), slide rasi bintang (1 set), peta bintang (1 buah) dan teleskop biasa dengan panjang $90 \mathrm{~cm}$ sebanyak 2 buah, sedangkan peralatan untuk praktikum bidang kebumian hanya ada model percobaan siklus air (1 buah). Kurangnya fasilitas peralatan sebenarnya dapat diantisipasi dengan membuat alat-alat peraga dari bahan di sekitar.

Hampir di semua sekolah tidak memiliki petunjuk praktikum IPBA. Di samping tidak ada petunjuk praktikum, peralatan lab IPBA juga sangat kurang. Hanya di beberapa sekolah saja yang punya alat lab., berupa model tata surya. Hal ini tentu berdampak pada hasil belajar siswa.

\section{3) Kendala-kendala yang dihadapi dan upaya antisipasi}

Kendala-kendala yang dihadapi dosen dan guru dalam pembelajaran praktikum IPBA yang teridentifikasi beserta antisipasi yang akan dilakukan antara lain:

a) Kemampuan guru dalam merancang dan melaksanakan kegiatan lab IPBA sangat perlu ditingkatkan. Untuk mengatasi hal ini, calon guru fisika perlu dibekali dengan kemampuan merancang dan melaksanakan kegiatan lab IPBA.

b) Tidak ada petunjuk praktikum. Untuk mengantisipasi hal ini, maka guru perlu diberikan bekal kemampuan dalam merancang dan melaksanakan praktikum IPBA.

c) Kurangnya alat praktikum IPBA maupun software/simulasi yang bisa digunakan untuk mendukung kegiatan lab IPBA di sekolah, bahkan di beberapa sekolah tidak memiliki peralatan IPBA. Hal ini dapat diantisipasi dengan membekali calon guru dengan kemampuan membuat alat peraga dari bahan-bahan yang ada di sekitar kita.

d) Mahasiswa cenderung pasif selama kegiatan pembelajaran. Aktivitas siswa dapat ditingkatkan dengan

Jurnal Pendidikan Indonesia |480 
memvariasi model pembelajaran, salah satunya dengan kegiatan laboratorium. Pembelajaran dengan kegiatan laboratorium diharapkan mampu meningkatkan aktivitas belajar siswa/mahasiswa karena mereka dilibatkan secara penuh selama pembelajaran.

Hasil studi lapangan terhadap pembelajaran IPBA dijadikan pertimbangan dalam pemilihan strategi/model pembelajaran praktikum IPBA berbasis kemampuan generik sains. Pembelajaran praktikum IPBA berbasis kemampuan generik sains yang dikembangkan diadaptasi dari model pembelajaran kemampuan generik Stasz (2001), dengan menambahkan tahap kolaborasi. Model pembelajaran ini, terdiri dari tujuh langkah pembelajaran dan dibagi dalam tiga tahap, yaitu: (1) modelling dan collaboration, (2) coaching, scaffolding, articulation dan reflection, serta (3) exploration. Sebelum itu calon guru diberikan pembekalan materi prasyarat dan dilakukan kegiatan apersepsi oleh dosen untuk memotivasi mahasiswa.

\section{4) Tes Keterampilan Laboratorium dan Kemampuan Generik Sains}

Tes kemampuan generik sains bidang IPBA yang dikembangkan terdiri dari dua jenis, yaitu tes kemampuan generik sains bidang Kebumian dan tes kemampuan generik sains bidang Astronomi. Bentuk awal dari tes kemampuan generik sains bidang Kebumian dan Astronomi masingmasing terdiri dari 33 dan 35 soal.

Tes praktikum IPBA yang dikembangkan juga terdiri atas dua bagian, yaitu tes praktikum Kebumian dan tes praktikum Astronomi. Bentuk tes praktikum berupa tes essay yang mengukur keterampilan mahasiswa dalam merancang, melaksanakan, dan melaporkan kegiatan laboratorium. Tes praktikum Kebumian terdiri dari lima butir soal dengan 15 sub butir soal dan tes praktikum Astronomi terdiri dari lima butir soal dengan 20 sub butir soal.

Selanjutnya draft perangkat pembelajaran dan instrumen tes yang dikembangkan akan divalidasi pada penelitian di tahun ke-2, sehingga diperoleh perangkat pembelajaran praktikum IPBA yang valid dan reliable.

\subsection{Pembahasan}

Berdasarkan analisis terhadap temuan pada studi literaturdi atas dapat diketahui bahwa, terdapat kesesuaian antara materi pada kurikulum IPBA di LPTK dengan di SMP/SMA (kurikulum 2006). Kesesuaian pada materi Kebumian terdapat pada pokok bahasan litosfer, hidrosfer, dan atmosfer, sedangkan pada Astronomi kesesuaian terlihat pada materi tentang matahari, bumi, bulan, bola langit, bintang dan jagat raya. Kesesuaian ini dijadikan sebagai salah satu pertimbangan dalam pemilihan topik-topik kegiatan laboratorium agar cakupan materi kegiatan laboratorium yang dirancang merepresentasikan keterampilan laboratorium yang dibutuhkan oleh calon guru IPBA.

Dari identifikasi terhadap temuan-temuan di atas, peneliti menemukan perlunya dilakukan perbaikan dan peningkatan kualitas pembelajaran IPBA di jurusan pendidikan fisika untuk meningkatkan kualitas lulusan calon guru fisika. Salah satu hal yang paling mendesak untuk dilakukan adalah peningkatan kualitas 
kemampuan calon guru dalam merancang dan melaksanakan kegiatan lab IPBA. Hal ini dilakukan dengan memberikan pembekalan kepada calon guru tentang kemampuan merancang dan melaksanakan kegiatan lab IPBA sekaligus mengembangkan alat peraga yang relevan. Agar kegiatan lab ini tidak hanya melatihkan hands on, maka rancangan kegiatan lab IPBA yang dilatihkan perlu berbasis kemampuan generik sains. Dengan mengembangkan kemampuan generik sains, calon guru juga dilatih untuk berpikir dan bertindak sesuai hakekat sains.

Berdasarkan hasil studi lapangan, sangat perlu kiranya dikembangkan petunjuk praktikum IPBA untuk mahasiswa calon guru fisika, sehingga setelah pembelajaran mahasiswa memiliki kemampuan dalam merancang praktikum, melaksanakan praktikum dan melaporkan hasil kegiatan praktikum. Karena peralatan lab IPBA masih banyak yang kurang, maka calon guru juga dilatih membuat alat-alat percobaan dari bahan-bahan yang ada di sekitar kita. Beberapa alat peraga yang perlu dibuat adalah: alat peraga pemekaran dasar samudera, erosi dan pelapukan, siklus air, efek rumah kaca dan jam matahari. Foto-foto alat peraga/percobaan yang dikembangkan untuk mendukung modul praktikum IPBA, terlampir.

Selain dikembangkan alat peraga yang sesuai dengan tuntutan modul praktikum, perangkat pembelajaran juga dilengkapi dengan pedoman pembelajaran, rubric penilaian kinerja proses dan produk, tes keterampilan IPBA, tes kemampuan generik sains dan angket untuk menggali respon mahasiswa. Dengan pengembangan draft perangkat praktikum IPBA disertai dengan model pembelajaran dan asesmennya, diharapkan dapat membantu guru dalam mengurangi hambatan dan kendala yang selama ini ditemukan, sehingga kemampuan calon guru dalam mengembangkan kegiatan praktikum IPBA dapat ditingkatkan.

\section{SIMPULAN DAN SARAN Simpulan}

Pertama, telah berhasil disusun Draft Perangkat Pembelajaran Praktikum Berbasis Kemampuan Generik Sains (P3BKGS) untuk bidang IPBA. Perangkat pembelajaran praktikum IPBA berbasis kemampuan generik sains, terdiri dari: silabus, modul praktikum/LKM, panduan untuk dosen, tes keterampilan praktikum, tes kemampuan generik sains berbasis konten, dan pedoman pengelolaan pembelajaran lengkap dengan asesmen dan rubrik penilaiannya yang dapat meningkatkan keterampilan laboratorium dan kemampuan generik sains mahasiswa pada mata kuliah IPBA.

Kedua, Model pembelajaran yang relevan untuk menerapkan MP2BKGS terdiri dari tujuh langkah dan dibagi dalam tiga tahap, yaitu: (1) modelling dan collaboration, coaching, scaffolding, articulation dan reflection, serta (3) exploration.

\section{Saran}

Berdasarkan temuan pada
penelitian tahun pertama ini disarankan agar ketiadaan fasilitas praktikum IPBA tidak dijadikan sebagai kendala utama, karena para guru bisa membuat alat-alat 


$$
\begin{aligned}
& \text { percobaan sederhana dengan } \\
& \text { memanfaatkan bahan yang ada di } \\
& \text { sekitar kita. }
\end{aligned}
$$

\section{DAFTAR PUSTAKA}

Brotosiswoyo, B.S. (2000). "Hakekat Pembelajaran Fisika di Perguruan Tinggi”, dalam Hakekat Pembelajaran MIPA \& Kiat Pembelajaran Fisika di Perguruan Tinggi. Jakarta: Proyek Pengembangan Universitas Terbuka. Departemen Pendidikan Nasional.

Depdiknas. (2002). Pengembangan Sistem Pendidikan Tenaga Kependidikan Abad ke-21 (SPTK21). Jakarta: Departemen Pendidikan Nasional.

Gibb, J. (2002). The Collection of Research Reading on Generics Skill in VET [Online]. Tersedia: http://www.ncvr.edu.au.hotm [ 2 Februari 2008]

Harlen, W. 1992. The Teaching Of Science. London: David Fulton Publishers.

Hartono. (2006). Pembelajaran Fisika Modern bagi Mahasiswa Calon Guru. Disertasi Doktor pada Sekolah Pascasarjana UPI. Bandung: tidak diterbitkan.

Hofstein, A. and Lunetta, V.N. (2004). "The Laboratory in Science Education: Foundations for the Twenty-First Century". Science Education. 88, 28-54.

Hofstein, A. and Mamlok-Naaman, R. (2007). "The Laboratory in Science Education: The State of The Art".
Chemistry Education Reserach and Practice. 8, (2), 105-107.

Iskandar. 1997. Pendidikan IImu Pengetahuan Alam. Jakarta: Departemen Pendidikan dan Kebudayaan Direktorat Jenderal Pendidikan Tinggi.

Lazzarowitz, R. and Tamir, P. (1994). "Research on Using Laboratory Instruction in Science", dalam Handbook of Research on Science Teaching and Learning, A Project of the NSTA. New York: John Wiley \& Sons. Inc.

Liliasari, Setiawan, A. dan Widodo, A. (2008). Model-model Pembelajaran Berbasis TI untuk Mengembangkan Keterampilan Generik Sains dan Berpikir Tingkat Tinggi Pembelajar. Laporan Penelitian HPTP pada Sekolah Pasca Sarjana UPI. Bandung: tidak diterbitkan.

Liliasari. (2005). Membangun Keterampilan Berpikir Manusia Indonesia Melalui Pendidikan Sains. Naskah Pidato IImiah pada Pengukuhan Guru Besar Pendidikan IPA UPI, Bandung. 23 November 2005.

Margono, H. (2000). Metode Laboratorium. Malang: Jurusan Biologi FMIPA Universitas Negeri Malang.

McDermot, L.C. (1990). "A Perspective on Teacher Preparation in Physic and Others Sciences: The Need for Special Science Courses for Teachers". American Journal Physics. 58, (8), 734-742. 
Millar, R. (2004). The Role of Practical Work in The Teaching and Learning of Science. Paper prepared for the Meeting: High School Science Laboratories: Role and Vision. National Academy of Sciences, Washington DC. June 3-4 2004.

NRC. (1996). National Science Education Standars. Washington D.C: National Academy Press.

Pujani, N.M., dan Liliasari. (2011). Deskripsi Hasil Analisis Pembelajaran IPBA sebagai Dasar Pengembangan Kegiatan Laboratorium Bagi Calon Guru. Makalah pada Seminar Nasional Pendidikan FKIP Unila, Bandar Lampung. 29-30 Januari 2011.

Pujani, N. M. 2010. Pembekalan Keterampilan Laboratorium Kebumian Berbasis Kemampuan Generik Sains Bagi Calon Guru Fisika. Laporan Penelitian Disertasi Doktor. SPs UPI. Bandung: tidak diterbitkan.

Rustad, S., Munandar, A. dan Dwiyanto. (2004). Analisis Prasarana dan Sarana Pendidikan SD/MI, SMP/MTS, dan SMA/SMK/MA. Jakarta: Balitbangnas, Departemen Pendidikan Nasional.

Rustaman, N.Y., Dirdjosoemarto, S., Yudianto, S.A., Achmad, Y.,
Subekti, R., Rochintaniawati, D. dan Nurjhani K., M. (2005). Strategi Belajar Mengajar Biologi. Malang: Universitas Negeri Malang (UM Press).

Stasz, C., Ramsey, K., Eden, R., DaVanzo, J., Farris, H. and Lewis, M. (2001). Classroom That Work: Teaching Generics Skills on Academic and Cocational Setting. MDS-263 [Online]. Tersedia: http://ncrve/Berkeley.edu. April 2009]

[15

Thiagarajan, S., Semmel, D.S. and Semmel, M.L. (1974). Instructional, Development for Training Teacher of Exceptional Children. Minnesota: Indiana University.

Tn. (2005). America's Lab. Report, Investigation in High School Science [Online]. Tersedia: http://books.nap.edu/open [28 Maret 2008].

VanCleave, J. (2004a). A+ Projects in Astronomy, Winning Experiments for Science Fairs and Extra Credit (terjemahan). Bandung: Pakar Raya.

VanCleave, J. (2004b). A+ Projects in Earth Science, Winning Experiments for Science Fairs and Extra Credit (terjemahan). Bandung: Pakar Raya. 